\title{
Association of oral candidiasis with diabetic control
}

\author{
L V H HILL, ${ }^{*}$ M H TAN, $†$ L H PEREIRA, $\ddagger$ J A EMBIL $\ddagger \S$ \\ From the Departments of * Obstetrics and Gynecology, $\dagger$ Endocrinology, $\ddagger$ Community Health and Epidemiology, \\ ๆMicrobiology, and §Pediatrics, Dalhousie University, Halifax, Nova Scotia, Canada
}

SUMMARY Factors associated with oral candidiasis in 51 diabetics were examined. The prevalence of oral yeast infection was $49(\mathrm{n}=25) \%$. The association with diabetic control, as measured by fasting blood glucose concentration, urinary glucose concentration, and glycosylated haemoglobin, with the presence of yeast was analysed in the 51 diabetic patients. Glycosylated ha?moglobin above $12 \%$ was strongly associated with oral yeast infection (odds ratio $=13.00)(p<0.001)$, while fasting blood and urinary glucose concentrations were not. The risk of oral candidiasis among diabetics wearing dentures was significantly higher than among dentate diabetics (odds ratio $=4 \cdot 78$ ). After controlling for the effect of denture wearing, glycosylated haemoglobin greater than $12 \%$ remained highly predictive of oral yeast infection, particularly among diabetics without dentures.

Degree of diabetic control, as measured by blood and urinary glucose concentration, has previously been associated with the presence of oral yeasts and humoral precipitating antibodies to Candida albicans in some studies. ${ }^{1}$ Other investigators have found that blood and urinary glucose concentrations were unrelated to oral candidiasis, ${ }^{2}$ even after diabetics and controls were matched for age, sex, smoking and dental state. ${ }^{3-6}$ Glycosylated haemoglobin (HbAlc) concentrations reflect the degree of diabetic control during the preceding two months. It has been shown that estimation of glycosylated haemoglobin is a better method of measuring diabetic control than the usual criteria of determining fasting blood glucose and glycosuria. ${ }^{78}$ This study assessed the value of using glycosylated haemoglobin concentrations to predict the prevalence of oral yeast in 51 diabetics in a multiple variable analysis, including age, sex, smoking and dental histories, blood and urinary glucose concentrations.

\section{Patients and methods}

The study population comprised 51 consecutive diabetic outpatients attending the diabetes clinic of the Victoria General Hospital in Halifax, Canada.

The palatal mucosa and denture base have been shown to support a high rate of yeast colonisation, ${ }^{9}$ so specimens for candidiasis were taken from these sites. The prevalence of oral yeasts was determined by

Accepted for publication 12 January 1989 obtaining fungal cultures from the palatal mucosa and denture base (if any) of each subject by rolling cotton swabs moistened in sterile water along the palatal mucosa or denture base and breaking them into a sterile glass phial containing $2 \mathrm{cc}$ of sterile water for transport to the laboratory.

Samples were streaked, using the four quadrant method with a $2 \mathrm{~mm}$ wire loop, on Saboraud's agar plates for semiquantitative analysis. After five to seven days' incubation at room temperature, increasing quantities were rated $1-4+$.

A streak was made across yeast colonies initially grown from the samples. These pooled yeast colonies were then streaked on Bromocresol green agar plates to distinguish between morphologically similar species. Single colonies were picked from each differently pigmented colony and grown on Saboraud's agar slants for examination of morphological and cultural properties. If no chlamydospores formed on Dalmau plates of cornmeal and Tween 80 agar, or if germ tubes did not form after 30 minutes' incubation in fetal calf serum at $37^{\circ} \mathrm{C}$, then API $20 \mathrm{C}$ (Analytab Products, Division of Ayerst Labs, Plainview, New York, USA) carbohydrate utilisation tests were carried out for identification of yeast species.

Three clinical chemistry tests were used to assess the degree of diabetic control. The fasting serum glucose concentration (Trinder glucose oxidase method; Boehringer-Manheim Corporation, 1974), degree of glycosuria (Chemstrip; Boehringer-Manheim Corporation), and glycosylated haemoglobin concentration (HA8110 BioRad Analyser; Daiichi, Japan) of 
each diabetic studied was taken on the day that oral yeast cultures were made.

Chandler and Chandler were able to show an increased carriage of $C$ albicans in diabetics with the poorest control, which they defined as "persistent fasting sugars above $200 \mathrm{mg} / \mathrm{dl}$, glycosuria equal to or greater than $3 \%$, and past episodes of diabetic ketoacidosis". ${ }^{6}$ Because of their findings, we analysed diabetic control by comparing fasting sugars above and below $12 \mathrm{mmol} / \mathrm{l}$ and urinary sugars above and below $3+(7 \mathrm{gl} \mathrm{dl})$. The normal range of glycosylated haemoglobin in routine use at the diabetes clinic was $5 \cdot 5-8 \cdot 2 \%$. In this study patients with poor diabetes control did not show evidence of oral yeast infection until HbAlc was $>12 \%$.

Data were analysed using the BMDP statistical programs. Odds ratios were calculated and Pearson $\chi^{2}$ tests were used to determine differences in proportions. Stepwise logistic regression analysis was applied to the data to adjust for the effects of extraneous variables.

\section{Results}

The mean age, age range, sex, presence or absence of dentures and smoking history of the 51 diabetics are shown in table 1 . Twenty five diabetics harboured oral yeasts. Species other than C albicans were found in two cases.

There was some variation in the $1+2+v 3+4+$ colony density, determined by four quadrant semiquantitative streaking of inoculum among subgroups of patients studied (table 2). Increased density is evident among denture wearers but not among smokers. Significant differences could not be determined due to the small size of the subsample of diabetics with yeast.

The risk of acquiring oral candiasis was significantly greater among diabetics wearing dentures than among those who did not (table 3). Those over 50 had an increased risk of yeast infection, but this age effect can be explained by the greater number of denture wearers among the older group (88.0\%) compared with those aged 50 and younger $(11.5 \%)$.

Table 1 Characteristics of sample population $(n=51)$

\begin{tabular}{ll}
\hline Mean age & $46 \cdot 4$ \\
Age range & $19-77$ \\
No of women & 30 \\
No of dentures & 25 \\
No of smokers & 16 \\
No of oral yeast infections & 25 \\
$\quad$ Candida albicans & 24 \\
Other yeasts & $2(1=$ mixed $)$ \\
Density (1+-2+ growth) & 13 \\
Density (3+-4+ growth) & 12 \\
\hline
\end{tabular}

Table 2 Density of yeast colonisation in subgroups of diabetics with oral yeast infection $(n=25)$

\begin{tabular}{|c|c|c|c|}
\hline & \multirow[b]{2}{*}{$n$} & \multicolumn{2}{|c|}{ Density $3+-4+$} \\
\hline & & Number & $(\%)$ \\
\hline \multicolumn{4}{|l|}{ Age } \\
\hline $\begin{array}{l}>50 \\
\leqslant 50\end{array}$ & $\begin{array}{l}(n=9) \\
(n=16)\end{array}$ & $\begin{array}{l}3 \\
9\end{array}$ & $\begin{array}{l}33 \cdot 3 \\
56 \cdot 2\end{array}$ \\
\hline \multicolumn{4}{|l|}{ Sex } \\
\hline $\begin{array}{l}\mathbf{F} \\
\mathbf{M}\end{array}$ & $\begin{array}{l}(n=15) \\
(n=10)\end{array}$ & $\begin{array}{l}7 \\
5\end{array}$ & $\begin{array}{r}46 \cdot 7 \\
50 \cdot 0\end{array}$ \\
\hline \multicolumn{4}{|l|}{ Dentures } \\
\hline $\begin{array}{l}\text { Yes } \\
\text { No }\end{array}$ & $\begin{array}{l}(n=17) \\
(n=8)\end{array}$ & $\begin{array}{r}10 \\
2\end{array}$ & $\begin{array}{l}58 \cdot 8 \\
25 \cdot 0\end{array}$ \\
\hline \multicolumn{4}{|l|}{ Smoker } \\
\hline $\begin{array}{l}\text { Yes } \\
\text { No }\end{array}$ & $\begin{array}{l}(n=8) \\
(n=17)\end{array}$ & $\begin{array}{l}3 \\
9\end{array}$ & $\begin{array}{l}37 \cdot 5 \\
52 \cdot 9\end{array}$ \\
\hline \multicolumn{4}{|c|}{ Glycosylated haemoglobin } \\
\hline $\begin{array}{l}>12 \% \\
\leqslant 12 \%\end{array}$ & $\begin{array}{l}(n=13) \\
(n=12)\end{array}$ & $\begin{array}{l}5 \\
7\end{array}$ & $\begin{array}{l}38 \cdot 5 \\
58 \cdot 3\end{array}$ \\
\hline \multicolumn{4}{|c|}{ Urinary sugar* } \\
\hline $\begin{array}{l}3+-4+ \\
0-2+\end{array}$ & $\begin{array}{l}(n=4) \\
(n=20)\end{array}$ & $\begin{array}{r}2 \\
10\end{array}$ & $\begin{array}{l}50 \cdot 2 \\
50 \cdot 2\end{array}$ \\
\hline $\begin{array}{l}\text { Fasting sugar } \\
>12 \mathrm{mmol} / 1 \\
\leqslant 12 \mathrm{mmol} / 1\end{array}$ & $\begin{array}{l}(n=12) \\
(n=13)\end{array}$ & $\begin{array}{l}5 \\
7\end{array}$ & $\begin{array}{l}41 \cdot 7 \\
53 \cdot 8\end{array}$ \\
\hline
\end{tabular}

*One specimen not available.

DEGREE OF DIABETIC CONTROL

Glycosylated haemoglobin concentrations above $12 \%$ were significantly associated with oral yeast infection ( $p<0.001$ ), while fasting blood glucose concentrations $>12 \mathrm{mmol} / \mathrm{l}$ and urinary glucose concentrations of $>3+$ were not (table 3). Age, sex, dental and smoking state, glycosylated haemoglobin, urinary and blood glucose concentrations were included in a logistic regression model. Stepwise analysis showed that dental state and glycosylated haemoglobin con-

Table 3 Potential risk factors for yeast infection among diabetics $(n=51)$

\begin{tabular}{|c|c|c|c|c|}
\hline & & $\begin{array}{l}\text { No with } \\
\text { yeast }(\%)\end{array}$ & $\begin{array}{l}\text { Odds } \\
\text { ratio }\end{array}$ & $\begin{array}{l}95 \% \\
\text { confidence } \\
\text { interval }\end{array}$ \\
\hline \multicolumn{5}{|l|}{ Age } \\
\hline $\begin{array}{l}>50 \\
\leqslant 50\end{array}$ & $\begin{array}{l}(n=25) \\
(n=26)\end{array}$ & $\begin{array}{r}16(64 \cdot 0) \\
9(34 \cdot 6)\end{array}$ & $\begin{array}{l}3.36 \\
(p=0.04)\end{array}$ & $(1.06,10.59)$ \\
\hline \multicolumn{5}{|l|}{ Sex } \\
\hline $\begin{array}{l}\text { Female } \\
\text { Male }\end{array}$ & $\begin{array}{l}(n=30) \\
(n=21)\end{array}$ & $\begin{array}{l}15(50 \cdot 0) \\
10(47 \cdot 6)\end{array}$ & $\begin{array}{l}1 \cdot 10 \\
(p=0.87)\end{array}$ & $(0 \cdot 36,3 \cdot 35)$ \\
\hline \multicolumn{5}{|l|}{ Dentures } \\
\hline Yes & $\begin{array}{l}(n=25) \\
(n=26)\end{array}$ & $\begin{array}{r}17(68 \cdot 0) \\
8(30 \cdot 8)\end{array}$ & $\begin{array}{l}4.78 \\
(p<0.01)\end{array}$ & $(1 \cdot 46,15 \cdot 62)$ \\
\hline \multicolumn{5}{|l|}{ Smoker } \\
\hline $\begin{array}{l}\text { No } \\
\text { Glvcosvlated ha }\end{array}$ & $(n=25)$ & $17(48 \cdot 6)$ & $(p=0.92)$ & \\
\hline $\begin{array}{l}\text { Glycosylated ha } \\
>12 \% \\
\leqslant 12 \%\end{array}$ & $\begin{array}{c}\text { emoglobin } \\
(\mathrm{n}=15) \\
(\mathrm{n}=36)\end{array}$ & $\begin{array}{l}13(86 \cdot 7) \\
12(33 \cdot 3)\end{array}$ & $\begin{array}{l}13.00 \\
(\mathrm{p}<0.001)\end{array}$ & $(2 \cdot 52,67 \cdot 19)$ \\
\hline \multicolumn{5}{|c|}{ Urinary glucose* } \\
\hline $\begin{array}{c}\begin{array}{l}3+-4+ \\
0-2+ \\
\text { Fasting glucose }\end{array}\end{array}$ & $\begin{array}{l}(n=7) \\
(n=39)\end{array}$ & $\begin{array}{r}4(57 \cdot 1) \\
20(51 \cdot 3)\end{array}$ & $\begin{array}{c}1 \cdot 27 \\
(p=0.78)\end{array}$ & $(0.25,6.42)$ \\
\hline $\begin{array}{l}>12 \mathrm{mmol} / 1 \\
\leqslant 12 \mathrm{mmol} / 1\end{array}$ & $\begin{array}{l}(n=18) \\
(n=33)\end{array}$ & $\begin{array}{l}12(66 \cdot 7) \\
13(39 \cdot 5)\end{array}$ & $\begin{array}{l}3.08 \\
(p=0.06)\end{array}$ & $(0 \cdot 92,10 \cdot 25)$ \\
\hline
\end{tabular}

*Five specimens not available. 
Table 4 Stratification of glycosylated haemoglobin concentrations by denture state

\begin{tabular}{|c|c|c|}
\hline & No & $\begin{array}{l}\text { Per cent } \\
\text { with yeast } \\
\text { infection }\end{array}$ \\
\hline \multicolumn{3}{|c|}{ Among those without dentures $(n=26)$} \\
\hline \multirow{2}{*}{$\begin{array}{l}\text { haemoglobin } \\
\text { Low glycosylated } \\
\text { haemoglobin }\end{array}$} & $7 / 9$ & $77 \cdot 8$ \\
\hline & $\begin{array}{c}1 / 17 \\
\chi^{2}=14.28, p=0.0002\end{array}$ & $5 \cdot 9$ \\
\hline \multicolumn{3}{|c|}{ Among those with dentures $\quad(n=25)$} \\
\hline \multirow{2}{*}{$\begin{array}{l}\text { haemoglobin } \\
\text { Low glycosylated } \\
\text { haemoglobin }\end{array}$} & $6 / 6$ & $100 \cdot 0$ \\
\hline & $\chi^{2}=\begin{array}{l}11 / 19 \\
3.72, p=0.0539\end{array}$ & $57 \cdot 9$ \\
\hline
\end{tabular}

centrations were the only variables to have a significant effect on the risk of oral yeast infection. The association of glycosylated haemoglobin concentrations with yeast infection was evaluated separately according to dental state (table 4). Because the likelihood of oral candidiasis among denture wearers is so high, the predictive potential of glycosylated haemoglobin concentration is most evident among diabetics without dentures. The individual associations between the percentage glycosylated haemoglobin and the presence or absence of yeasts is shown in table 5 .

\section{Discussion}

The association between diabetic control and fungal infection was examined by comparing urinary glucose concentrations (which are a poor index of glycaemia), fasting blood glucose (which reflect the degree of glycaemia at one point in time), and glycosylated haemoglobin concentrations (which reflect the degree of glycaemia during the preceding two months) among the 51 diabetic outpatients studied. Degree of control as measured by fasting sugars and urinary glucose concentrations was unrelated to prevalence of oral candidiasis, confirming earlier reports. ${ }^{23}$ Glycosylated haemoglobin concentrations above $12 \%$ were significantly associated with oral yeast infection, which suggests that fungal infections of mucous membranes may only be significantly associated with diabetes in patients with a longer history of hyperglycaemia. Being diabetic in itself may not place a person at increased risk of fungal infection, unless diabetic control is very poor, as evidenced by glycosylated haemoglobin concentrations of more than $12 \%$ (table 3).

Because of the common belief that diabetes of any degree is associated with an increased risk of fungal infection, many people with recurrent genital candidiasis are screened for diabetes mellitus. Only 15 $(10.9 \%)$ of 138 men with candidal balanitis were diabetic in an uncontrolled trial of $1 \%$ clotrimazole (Canestan) cream, and this group was significantly older than the non-diabetics studied. ${ }^{10}$ In a study of the microbial flora of the vagina in 90 diabetic and nondiabetic women there was no difference between diabetic and non-diabetic patients in the isolation of $C$ albicans, ${ }^{11}$ even when diabetic control was poor. Among 85 women with alleged recurrent vulvovaginal candidiasis, there were no abnormal blood glucose concentrations detected two hours after eating; and among 250 women referred for this disorder, over $80 \%$ had been tested by their practitioners for subclinical diabetes and all were found to be normal. ${ }^{12}$ Similarly, glucose tolerance curves in 72 pregnant women with vaginal candidiasis confirmed by culture did not differ from those of an equal number of matched controls. ${ }^{13}$ These studies suggest that in women genital candidiasis is rarely associated with diabetes, while $89 \%$

Table 5 Association between percentage of glycosylated haemoglobin and presence or absence of oral yeasts

\begin{tabular}{|c|c|c|c|c|c|c|c|c|c|c|c|c|c|}
\hline$\frac{\text { Case No }}{7}$ & \multicolumn{13}{|c|}{ Percentage of glycosylated haemoglobin } \\
\hline $\begin{array}{l}7 \\
6 \\
5 \\
4 \\
3 \\
2 \\
1 \\
0\end{array}$ & $\begin{array}{r}\mathbf{X} \\
\mathbf{X} \\
\mathbf{O X}\end{array}$ & $\begin{array}{l}\mathrm{O} \\
\mathrm{O} \\
\mathrm{OX}\end{array}$ & $\begin{array}{l}\text { O } \\
\text { O } \\
\text { O } \\
\text { O } \\
\text { OX } \\
\text { OX } \\
\text { OX }\end{array}$ & $\begin{array}{r}\mathbf{X} \\
\underset{\mathbf{X}}{\mathbf{X}} \\
\mathbf{X} \\
\mathbf{X} \\
\mathbf{O X} \\
\mathbf{O X} \\
\mathbf{O X}\end{array}$ & $\begin{array}{l}\text { O } \\
\text { O } \\
\text { O } \\
\text { O } \\
\text { O } \\
\text { O } \\
\text { O } \\
\text { O } \\
\text { O } \\
\text { O } \\
\text { OX } \\
\text { OX } \\
\text { OX } \\
\text { OX } \\
\text { OX }\end{array}$ & $\begin{array}{l}\mathbf{O} \\
\mathbf{O} \\
\mathbf{O} \\
\mathbf{O} \\
\mathbf{O} \\
\mathbf{O} \\
\mathbf{O X} \\
\mathbf{O X} \\
\text { OX } \\
\text { OX } \\
\text { OX } \\
\mathbf{O}\end{array}$ & $\begin{array}{l}\text { O } \\
\text { O } \\
\text { O } \\
\text { O } \\
\text { O } \\
\text { O } \\
\text { O } \\
\text { O } \\
\text { OX } \\
\text { OX } \\
\text { OX } \\
\text { OX } \\
\text { OX } \\
\text { OX } \\
\text { OX }\end{array}$ & $\begin{array}{r}\mathbf{X} \\
\mathbf{X} \\
\mathbf{X} \\
\mathbf{X} \\
\mathbf{X} \\
\mathbf{O X} \\
\mathbf{O X} \\
\mathbf{O X} \\
\mathbf{O X} \\
\mathbf{O X} \\
\mathbf{O X}\end{array}$ & $\begin{array}{r}\mathbf{X} \\
\underset{\mathbf{X}}{\mathbf{X}} \\
\mathbf{X} \\
\mathbf{X} \\
\mathbf{X} \\
\mathbf{O} \\
\mathbf{X}\end{array}$ & $\begin{array}{r}\mathbf{X} \\
\mathbf{X} \\
\mathbf{X} \\
\mathbf{X} \\
\mathbf{O} \\
-\end{array}$ & $\begin{array}{r}\mathbf{X} \\
\mathbf{X} \\
\mathbf{X} \\
\mathbf{X} \\
\mathbf{X} \\
-\end{array}$ & $\begin{array}{r}\mathbf{X} \\
\mathbf{X} \\
\mathbf{X} \\
\mathbf{O X}\end{array}$ & $\underset{\text { OX }}{\mathbf{X}}$ \\
\hline & $0-6$ & 7 & 8 & 9 & 10 & 11 & 12 & 13 & 14 & 15 & 16 & 17 & 18 \\
\hline
\end{tabular}

$\mathrm{O}=$ no yeast $\mathbf{X}=$ oral yeast. 
of men with genital candidiasis are also not diabetic. The same principle may apply in oral candidiasisthat is, most people with oral yeasts are not diabetic; but very poorly controlled diabetics are significantly more likely to have oral candidiasis as this study suggests.

Tobacco smoking and wearing dentures continuously day and night have been found to be important local factors in chronic oral hyperplastic candidiasis. ${ }^{14}$ In the present study the presence of dentures and glycosylated haemoglobin concentrations were independent predictors of the risk of developing candidiasis. This finding suggests that diabetics are relatively more susceptible to fungal infections in areas of moisture and trauma, but in the absence of dentures a high glycosylated haemoglobin concentration is an important risk factor for yeast infection.

We thank the Dalhousie Research Foundation for providing the Research Studentship that funded LVHH during this investigation.

\section{References}

1 Odds FC, Evans EGV, Taylor MAR, Wales JK. Prevalence of pathogenic yeasts and humoral antibodies to Candida in diabetic patients. J Clin Pathol 1978;31:840-4.

2 Barlow AJE, Chattaway FU. Observations on the carriage of Candida albicans in man. Br J Dermatol 1969;81:103-7.

3 Tapper-Jones LM, Aldred MJ, Walker DM, Hayes TM. Candidal Infections and populations of Candida albicans in mouths of diabetics. J Clin Pathol 1981;34:706-11.
4 Bastiaan RJ, Reade PC. The prevalence of Candida albicans in the mouths of tobacco smokers with and without oral mucous membrane keratoses. Oral Surg 1982;53:148-51.

5 Arendorf TM, Walker DM. The prevalence and intraoral distribution of Candida albicans in man. Arch Oral Biol 1980;25:1-10.

6 Chandler PT, Chandler SD. Pathogenic carrier rate in diabetes mellitus. Am J Med Sci 1977;273:259-65.

7 Nathan DM, Singer DE, Hurxthal K, Goodson JD. The clinical information value of the glycosylated hemoglobin assay. $N$ Engl J Med 1984;310:341-6.

8 Health and Public Policy Committee. American College of Physicians. Position paper. Glycosylated hemoglobin assays in the management and diagnosis of diagetes mellitus. Ann Intern Med 1984;101:710-3.

9 Bergendal T, Holmberg K, Nord CE. Yeast colonization in the oral cavity and feces in patients with denture stomatitis. Acta Odontologica Scand 1979;37:37-45.

10 Waugh MA, Evans EGV, Nayyar KC, Fong R. Clotrimazole (Canestin)* in the treatment of candidal balanitis of men. British Journal of Venereal Disease 1978;54:184-6.

11 Williams DN, Knight AH, King H, Harris DM. The microbial flora of the vagina and its relationship to bacteruria in diabetic and non-diabetic women. Br J Urol 1975;47:453-7.

12 Sobel JD. Vulvovaginal candidiasis-what we do and do not know. Ann Int Med 1984;101:390-2.

13 Robinson SC, Nicholas WC, Lee DT, Wanklin JM, Zwicker B. The relationship of pregnancy, vaginal candidiasis and glucose metabolism. Can Med Assoc J 1967;96:583-4.

14 Arendorf TM, Walker DM, Kingdom RJ, Roll JRS, Newcombe RG. Tobacco smoking and denture wearing in oral candidal leukoplakia. Br Dent J 1983;155:340-3.

Requests for reprints to: Dr Juan A Embil, Infection and Immunology Research Laboratory, Izaak Walton Killam Hospital for Children, 5850 University Avenue, Halifax, Nova Scotia, Canada B3J 3G9. 